\title{
DIFFERENT STRATEGIES OF THE GREEK FATHERS AGAINST THE PNEUMATOMACHIANS
}

The question of the origin of the pneumatomachian heresy and of its link with Macedonius, Bishop of Constantinople, is still open. This historical uncertainty is also reflected from the perspective of the history of dogma, and

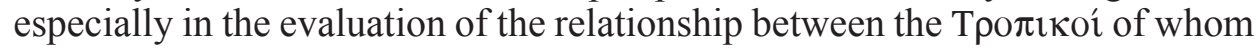
Athanasius speaks, the opponents of the o $\mu$ o $\tau \mu \mu^{i} \alpha$ to which Basil responds ${ }^{1}$, and the Macedonians, of which there are records from the end of the fourth century. It is not clear why it was only in 380 that the latter began to be called by this name ${ }^{2}$, when Macedonius had died in 360 and there was no lack of discussions about the Holy Spirit in the privious years ${ }^{3}$. However, most important from the theological point of view is the clarification of their relationship with the homoiousians ${ }^{4}$.

This question was especially well explored in the German world in reference to the presumed binitarianism of Eusebius and to the role of Marcellus. The pneumatomatic heresy would be connected to Eusebian ambits ${ }^{5}$, where the Origen's legacy had been received only in part with regard to the third Person $^{6}$. The theology of the $\Lambda$ ó $\gamma$ os which characterizes the thought of Eusebius would obscure the role of the Spirit, which was presented by Origen in his Trinitarian construction with some uncertainty. In a very brief summary, Georg Kretschmar and Wolf-Dieter Hauschild have highlighted the binitarianism of

* Prof. Giulio Maspero - Extraordinary Professor of Dogmatic Theology (Chair: "The mystery of one and triune God") at the Pontifical University of the Holy Cross - Rome (Italy); e-mail: maspero@pusc.it.

${ }^{1}$ Cf. M.J. Larson, A Re-examination of De Spiritu Sancto: Saint Basil's Bold Defence of the Spirit's Deity, „Scottish Bulletin of Evangelical Theology” 19 (2001) 65-84.

${ }^{2}$ Cf. Hieronymus, Chronicon, ed. R. Helm, GCS 47, Eusebius Werke 7, Berlin 1956, 235.

${ }^{3}$ One of the best studies of this period is found in M.A.G. Haykin, The Spirit of God: The Exegesis of 1 and 2 Corinthians in the Pneumatomachian Controversy of the Fourth Century, Leiden 1994.

${ }^{4}$ On the complexity of the relationship between the Pneumatomachians, Macedonians, and Homoiousians, see P. Meinhold, Pneumatomachoi, RACh XXI 1066-1087.

${ }^{5}$ Cf. D.M. Gwynn, The Eusebians. The Polemic of Athanasius of Alexandria and the Construction of the "Arian Controversy", Oxford 2007.

${ }^{6}$ Cf. V.H. Drecoll, Die Entwicklung der Trinitätslehre des Basilius von Cäsarea. Sein Weg vom Homöusianer zum Neonizäner, Göttingen 1996, 140. 
Eusebius, with the former attributing its cause to the very Bishop of Caesarea ${ }^{7}$, and the latter emphasizing its continuity with Origen through a more severe judgment concerning the Trinitarian insufficiency of the Alexandrinian ${ }^{8}$. Holger Strutwolf subsequently criticized such positions, highlighting the presence of an authentic pneumatology in Eusebius, insufficient though it is ${ }^{9}$. Volker Henning Drecoll, finally, has shown the role that Marcellus plays in spurring Eusebius to develop an outline of pneumatology ${ }^{10}$.

This discussion reveals a remarkable wealth from the standpoint of the history of dogma and provokes interest in studying the different strategies that various authors had developed in order to respond to criticisms by the Pneumatomachians in the second half of the fourth century. This is a time far removed from the discussion between Marcellus and Eusebius, but fundamental for the role of the Council of Constantinople in the definition of the divinity of the third Person. The perspective of the present paper is essentially dogmatic, which is why the most common arguments of the Pneumatomachians alongside the responses of the Orthodox in three texts that are explicitly dedicated to the refutation of this heresy will be presented together and analized.

1. Epiphanius of Salamis. An early example of the strategies of responding to the Pneumatomachians in this period is that of Epiphanius of Salamis, who wrote around 375 in Palestine, where his monastery was a Nicaean stronghold. In Panarion, at no. 54 (74), he deals with these heretics, defining them as monstrous beings, who are only half-formed and of a dual nature ( $\tau \varepsilon \rho \alpha ́ \sigma \tau \imath$ เ

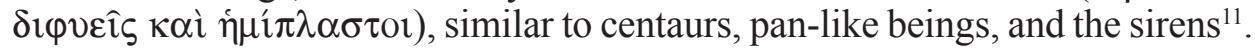
The central point in the description of the heresy is the equating of the Spirit to a creature, while the Son is considered coeternal with the Father ${ }^{12}$.

The body of Epiphanius' disproof consists of his insertion into the Panarion of a long, more directly pneumatological section, from Ancoratus $^{13}$. This has the Word as its proper starting point, bearing witness to the connection with Semi-Arianism. Clearly the argumentative strategy, which is always essentially scriptural in the Bishop of Salamis, aims to put the second and third Person of the Trinity on the same level. That is why he emphasizes how they

\footnotetext{
${ }^{7}$ Cf. G. Kretschmar, Studien zur frühchristlichen Trinitätstheologie, Tübingen 1956, 2-14.

${ }^{8}$ Cf. W.-D. Hauschild, Die Pneumatomachen. Eine Untersuchung zur Dogmengeschichte des vierten Jahrhunderts, Hamburg 1967 (PhD thesis), 131-140 and 151-152.

${ }^{9}$ Cf. H. Strutwolf, Die Trinitätstheologie und Christologie des Euseb von Caesarea. Eine dogmengeschichtliche Untersuchung seiner Platonismusrezeption und Wirkungsgeschichte, Göttingen 1999.

${ }^{10}$ Cf. V.H. Drecoll, How Binitarian/Trinitarian was Eusebius?, in: Eusebius of Caesarea. Tradition and Innovations, ed. A. Johnson - J. Schott, Cambridge 2013, 289-305.

${ }^{11}$ Cf. Epiphanius, Panarion 74, 1, 1, ed. K. Holl, GCS 37, Berlin 1985, 313, 12-13.

${ }^{12}$ Cf. ibidem 74, 1, 2-4, GCS 37, 313, 19-24.

${ }^{13}$ Cf. idem, Ancoratus 65, 1 - 73, 9 .
} 


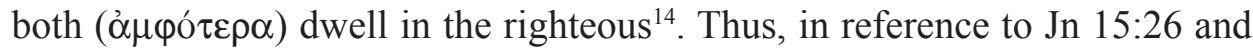
16:14, Epiphanius immediately adds:

"And if one believes that Christ is of the Father as God from God ( $\theta \varepsilon \dot{s} \varsigma \dot{\varepsilon} \kappa$ $\theta \varepsilon \circ \widehat{v})$, the Spirit is from Christ, indeed from both ( $\left.\pi \alpha \rho^{\prime} \alpha \dot{\alpha} \mu \varphi \sigma \varepsilon \dot{\varepsilon} \rho \omega \nu\right) " 15$.

Thus, salvation comes from the entire Trinity, in such a way that from the soteriological and economic perspective one may ascend to the immanent perspective:

"Three Holy Ones who are altogether one holinesses, three existences

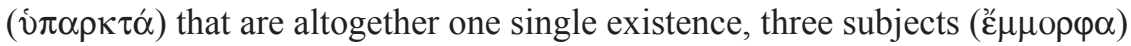

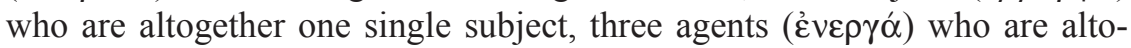
gether one single agent, three subsistences $(\dot{\varepsilon} v v \pi$ ó $\sigma \tau \alpha \tau \alpha)$ who are altogether

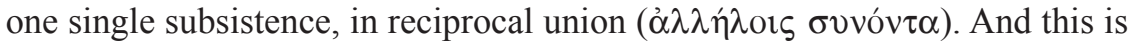
called the Holy Trinity, because the three are a single divinity inasmuch as they are a single harmony ( $\left.\sigma \nu \mu \varphi \omega v^{\prime} \alpha\right)$ of the same substance, of the same

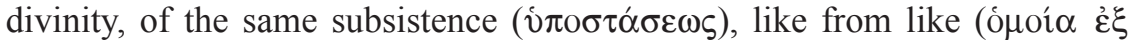
ónoíov). In fact, identical is the grace of the Father, of the Son, and of the Holy Spirit that is operative, and it is up to them to teach it" ${ }^{\prime \prime}$.

Note how even the Holy Spirit is denoted by the term Évv $\pi$ ó $\sigma \tau \alpha \tau o v^{17}$, which seems to perform a specific role in this area of discussion. Epiphanius emphasizes the relational unity of the three divine Persons, each of whom is perfectly identified with the unique divine substance and is present in the unique action, while the personal distinction is formulated on a prepositional level that expresses reciprocal relations: "because they are three as from, for, and toward

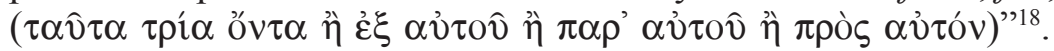

The Son and the Spirit are both sent by the Father, in such a way that, if the former made Himself a servant ( $\delta$ iókovov), the latter made Himself a servant alongside Him ( $\sigma v v \delta 1 \alpha \kappa o v \varepsilon \hat{\imath} v)$, which is why Scripture teaches that both Persons speak in the saints, heal, sanctify, and baptize ${ }^{19}$. The text is full of citations, which range from the Trisagion in Is 6:3 to the command to not grieve the Spirit of Eph 4:30, up to the deception of Ananias in Acts 5:3-4, on which Epiphanius comments with a significant expression:

"So also the Holy Spirit is God as God from God ( $\theta \varepsilon \dot{\varsigma} \zeta \dot{\varepsilon} \kappa \theta \varepsilon \circ \hat{v})$, inasmuch as those who had kept a part of the earnings for themselves lied to God himself"20.

${ }^{14}$ Cf. ibidem 66, 12, 3-5.

${ }^{15}$ Ibidem 67, 1, 1-2, ed. K. Holl, GCS 25, Leipzig 1915, 81, transl. by the author.

${ }^{16}$ Ibidem 67, 4, 3 - 67, 5, 1, GCS 25, 82, transl. by the author.

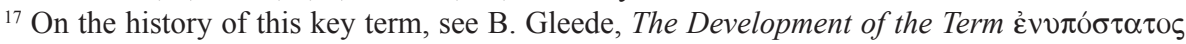
from Origen to John of Damascus, Leuven 2012.

${ }^{18}$ Epiphanius, Ancoratus 67, 6, 1-2, GCS 25, 82.

${ }^{19} \mathrm{Cf}$. ibidem, 68, 1-2.

${ }^{20}$ Ibidem 69, 8, 17-18, GCS 25, 86. 
We therefore arrive at the dogmatic core of Epiphanius' theological demonstration, which from the unity of action of the three divine Persons goes back to their distinction and mutual immanent relation. Ps 32(33):6, an especially important verse in the pneumatomatic dispute ${ }^{21}$, is cited as proof of the synergy of the Father, of the Son, and of the Holy Spirit, by virtue of the dual reference to the creative act and to the distinction with respect to the angels. This citation is immediately linked to Jn 4:24 as an indication of the necessity of also adoring the third Person ${ }^{22}$. In fact, it is precisely the creative act that radically differentiates the Father, the Son, and the Spirit from any creature:

"But if [the Spirit] makes together these things, a creature does not produce a creature, nor does the divinity become created, nor is He known as God according to a limited and partial sense. In fact, the divinity is without limits,

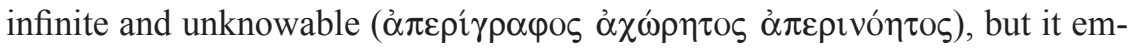
braces all that God has made" 23 .

Therefore, not adoring the third Person would be equivalent to a violation of the first commandment of Deut 6:4. The reasoning is at the same time deeply biblical and authentically ontological. The presence of these metaphysical inclusions are particularly surprising in the discourse of Epiphanius, who does not work in more philosophically sophisticated areas as Gregory of Nyssa does. However, the line of reasoning is similar and clear: "If God and Father is

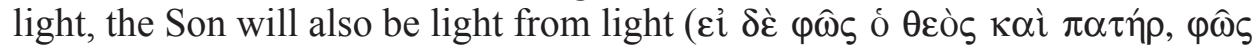

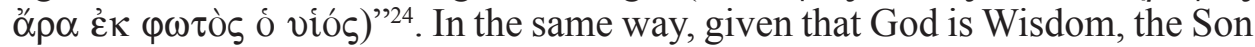

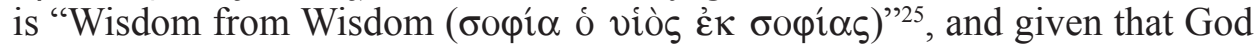

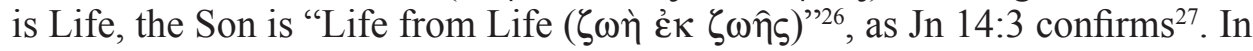
the same way, applying the fundamental principle of his refutation, Epiphanius adds, with regard to the third Person in His relation to the Father and the Son: "And the Spirit, being from both, is Spirit from Spirit ( $\tau$ ò $\delta \varepsilon \grave{\alpha} \alpha \gamma ı v \pi v \varepsilon \hat{v} \mu \alpha$

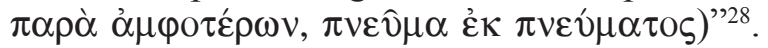

Note how in the reasoning proposed by the Bishop of Salamis, the third Person's relation of origin to both the first two Persons is the basis for his

${ }^{21}$ Cf. G. Maspero, Dallo Spirito vivificatore allo Spirito Creatore: l'esegesi cappadoce di Sal 32(33),6, in: Creazione e salvezza nella Bibbia: atti dell'XI Convegno internazionale della Facoltà di teologia, Roma, 8-9 marzo 2007, ed. M.V. Fabbri - M. Tábet, Roma 2009, 407-426.

${ }^{22}$ Cf. Epiphanius, Ancoratus 70, 1-2.

${ }^{23}$ Ibidem 70, 2, 1 - 70, 3, 1, GCS 25, 87.

${ }^{24}$ Ibidem 70, 5, 2 - 70, 6, 1, GCS 25, 87.

${ }^{25}$ Ibidem 70, 6, 3, GCS 25, 88.

${ }^{26}$ Ibidem 70, 7, 1, GCS 25, 88.

${ }^{27}$ Cf. G. Maspero, Life from Life: The Procession of the Son and the Divine Attributes in Ch. VIII of Gregory of Nyssa'a Contra Eunomium III, in: Gregory of Nyssa's Contra Eunomium III. Proceedings of the Twelfth International Gregory of Nyssa Colloquium (Leuven, 14-17 September 2010), ed. J. Leemans - M. Cassin, Leuven 2014, 423-427.

${ }^{28}$ Epiphanius, Ancoratus 70, 7, 1-2, GCS 25, 88. 
affirmation that both the Son and the Spirit are God. From the perspective of his opponents the divinity of the second Person is acceptable, even if this is not affirmed with the same strength as the Nicaeans do. Epiphanius' response thus presents the second procession alongside the first, in such a way that the fact of the Father and the Son being only one substance implies per se that the Spirit proceeds from both, because the latter proceeds as Spirit from Spirit. In this way the affirmation of the perfection of the first procession is the basis for the full formulation of the second procession.

From here the necessity of distinguishing the two processions clearly emerges. Thus, Epiphanius responds immediately to a fundamental objection that recurs in his debate with the pneumatomachians:

"But one may object: therefore we say that there are two sons, but then how is [the Son] Unbegotten? «But who indeed are you, a human being, to talk back to God?» (Rom 9:20) In fact, if he calls the Son the one who is from Him, he also calls the Holy Spirit the one who is from both ( $\pi \alpha \rho$ ' $\alpha \mu \varphi \sigma \tau \varepsilon \rho \omega v)$. These two Persons, who are known by the saints only through faith, are light and they communicate light, and their operation is illuminating and carrying out harmony ( $\sigma u \mu \varphi \omega v i \alpha v)$ with the Father of light. Listen, therefore, with faith, that the Father, who is all Light, is the Father of the true Son, and the Son is Son of the true Father, as Light from Light, not just nominally like what is made or created. And the Holy Spirit is Spirit of Truth, third Light that is from

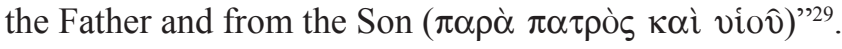

Thus, just as the Father neither began to be nor ceases to be Father, unlike the patriarchs and human fathers who in turn are someone's son ${ }^{30}$, so also the Holy Spirit was not created as were the angels and other spirits, even though Isaiah calls Him "Angel of the Great Council" (Is 9:6; LXX). In fact, His spiration neither has a beginning nor an end, and it is incomprehensible, unlike what occurs on the level of creatures, which are in time but depend on Him who

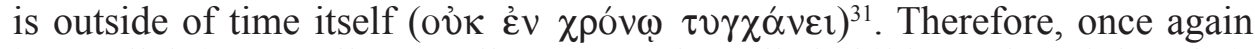
in parallel, just as all generally come to be called children of God, but their generation is essentially different from that of the Son, insofar as it is limited, in the same way Scripture uses the term spirits with diverse meanings, but the Holy Spirit alone is Spirit of the Father and of the Son ${ }^{32}$.

The entire demonstrative strategy culminates in the theological affirmation that the Holy Spirit is a subsistent subject, through the term हैvv $\pi$ ó $\sigma \tau \alpha \tau o v^{33}$, and the expression used is typical of the vocabulary of Epiphanius. This point is essential because the divine nature is all spirit and all holy, and this is revealed

\footnotetext{
${ }^{29}$ Ibidem 71, 1, 1 - 71, 3, 1, GCS 25, 88.

${ }^{30} \mathrm{Cf}$. ibidem $71,4,1-71,6,1$.

${ }^{31} \mathrm{Cf}$. bidem 71, 7, $1-71,8,3$.

${ }^{32} \mathrm{Cf}$. ibidem 72, 6, 1-5.

${ }^{33}$ Cf. ibidem 72, 8, 3-4.
} 
in God's own activity, but here we are dealing with the recognition of the third divine Person as God starting from His relations with the other two. In a concise formula, Epiphanius affirms in Panarion, taking back up the discussion after the long insertion of Ancoratus, that "As God is one, and one alone is the Only Begotten Son of God, so also the Holy Spirit of God is one alone: of God and in

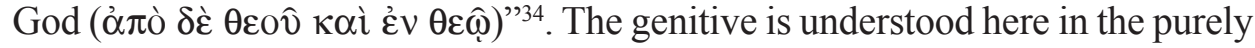
immanent sense, so as to state the divine attributes for each divine Person and to conclude that "the Trinity is eternally Trinity and does not receive any addition ('A

In summary, this work seeks to address the heart of the pneumatological question, that is, it affirms not only that God is spirit, but also that the Spirit is God, understood here as a divine Person and not as divine attribute. The strategy of Epiphanius follows the derivative way, in order to show that the third Person of the Trinity is Spirit from Spirit, because in the divine immanence He proceeds from both of the first two Persons. The synergy and distinction of the two processions are the main dogmatic elements that are in play in this debate. However, other possibilities are added to this responsive strategy.

2. Pseudo-Athanasius. a) First Part. The two Pseudo-Athanasian treatises against the Macedonians (CPG 2285), recorded in PG 28, 1291-1338, have a complex history, both from a redactional standpoint and from a theological standpoint ${ }^{36}$. Elena Cavalcanti, in her edition of the text and in the analyses that accompany $\mathrm{it}^{37}$, emphasizes how the two works can be read in a unitarian way from the point of view of the intention of the redactor. At the same time the presence of a first section in the first dialogue (cc. 1-8), consisting of earlier material than the final drafting, is quite evident. According to the analysis by Loofs this first section would present an anti-Macedonian dossier dating back to the years between 381 and $390^{38}$. This is why it seems appropriate to distinguish the arguments of the two parts of the first treatise. As mentioned, the aim of the present paper is laying out the dogmatic arguments advanced by the Pneumatomachians and also the responses from the Orthodox side, without advancing in a detailed historical and philological analysis.

${ }^{34}$ Idem, Panarion 74, 11, 5, GCS 37, 329, 11-13.

${ }^{35}$ Ibidem 74, 12, 1, GCS 37, 329, 27-28.

${ }^{36}$ Cf. Ch. Bizer, Studien zu pseudathanasianischen Dialogen der Orthodoxos und Aëtios, Bonn 1970; A. Segovia, Contribucion al estudio de la tradicion manuscrita dei pseudoatanasiano. "Dialogo I contra un Macedoniano o pneumatomaco", "Archivio Teológico Granadino" 1 (1938) 87107; and A. Günthör, Die 7 pseudoathanasianischen Dialogen ein Werk Didymus' des Blinden von Alexandrien, Dissertation, Pontifical Atheneum of St. Anselm, Roma 1940.

${ }^{37}$ Cf. Pseudo-Atanasio, Dialoghi contro i Macedoniani, Introduzione, testo critico, traduzione, commento e indici a cura di E. Cavalcanti, Corona Patrum 10, Torino 1983.

${ }^{38}$ Cf. ibidem, p. 17. 
From this standpoint, the first argument of the doctrinal file ( $\sigma \chi \varepsilon \delta$ óp $\rho \circ)^{39}$ of the heretical part is the clear affirmation that "If the Holy Spirit is God, either $\mathrm{He}$ is the Father or $\mathrm{He}$ is the Son, otherwise He does not exist" ${ }^{40}$. This either-or is put in crisis - in the etymological sense of judgment - by the Orthodox response, which distinguishes the ontological dimension of nature from that of person: the Father is not God because He is Father, otherwise the Son could not be God because as the Son He is not Father, and vice versa. Therefore, the Holy Spirit is also God and not because He is Father or Son ${ }^{41}$. The underlying dogmatic and ontological reason is as follows:

"God in fact indicates a nature ( $\varphi v \varepsilon \sigma \omega \varsigma)$ that contemplates and fills the entire universe; Father, rather, is the name of a relation ( $\sigma \chi \varepsilon \tau \imath \kappa o ́ v)$, as is Son. The name of the relation ( $\tau \grave{o} \tau \hat{\eta} \varsigma \sigma \chi \varepsilon \dot{\varepsilon} \sigma \varepsilon \omega \varsigma$ övo $\mu \alpha$ ) does not signify the nature that fills and contemplates, nor does the name of the nature that fills and contemplates introduce the relation ( $\sigma \chi \varepsilon \dot{\varepsilon} \sigma \mathrm{v})$ of the Father to the Son"42.

Here the Macedonian critique to the doxology makes its appearance, translating the previous exchange in terms of worship $(\pi \rho \circ \sigma \kappa v v \eta \tau \varepsilon \text { ov })^{43}$. The response follows, therefore, in the line begun, distinguishing the plane of nature and that of the person:

"If this is the reason why you worship the Father, that is, because He is Father, and the Son, that is, because He is Son, then you worship every father and every son" ${ }^{\prime \prime 4}$.

Rather, one must adore the first two Persons of the Trinity because they have

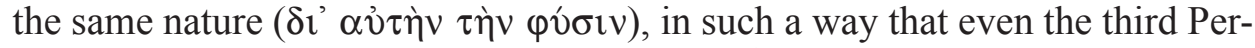
son will be adored, if $\mathrm{He}$ is of the same nature ${ }^{45}$.

On the Macedonian side the counter-argument to the Orthodox response is that even when Jn 4:24 says that God is Spirit, it is not interpreted to mean that every spirit is God, suggesting in an analogous way that every father and every son are not $\mathrm{God}^{46}$. The scriptural standpoint of the counter-argument is advanced by the Orthodox to observe that not even all of what is called God is spirit, as Moses is called god in Ex 7:1. In the same way as in the New Testament, Jn 10:35 attributes to Christ the statement that the saints are gods. Such

${ }^{39}$ The term appears three times in the dialogue, in 1, 4; 6, 30 and 9, 4, but it is rather rare. It is found, for example, two times in the Anacephalaeosis, which is a work of uncertain attribution to Epiphanius (De fide 25, 3, GCS 37, 526, 5 and 8) and one time in De eleemosyna of the PseudoChrysostomus (PG 60, 710B).

${ }^{40}$ Pseudo-Athanasius, Dialogi contra Macedonianos I 1, 1, ed. Cavalcanti, p. 50.

${ }^{41}$ Cf. ibidem I 1, 2-9.

${ }^{42}$ Ibidem I 1, 10-14, ed. Cavalcanti, p. 52.

${ }^{43}$ Cf. ibidem I 1, 16.

${ }^{44}$ Ibidem I 2, 1-3, ed. Cavalcanti, p. 52.

${ }^{45} \mathrm{Cf}$. ibidem I 2, 5-8.

${ }^{46} \mathrm{Cf}$. ibidem I 2, 10-11. 
citations are many, from Ps 49:1 to Ps $83: 8$ and Ps $81: 1$ up to Ex 22:27. The conclusion is that not all of what is called god is also spirit and not all of what is called spirit is god. Also introduced here is the paradoxical example of demons, which are spirits but are not $\mathrm{God}^{47}$.

In light of all this, the discussion shifts to the identification of the Spirit with the Lord, taking 2Cor 3:13 as the starting point. The Macedonian objection here is that the third Person is not God, but the $\operatorname{Lord}^{48}$. This also introduces the Christological theme, which in the final redaction is developed in the last part of the first treatise and the body of the second, because of the necessity of determining the ontological relationship between the Spirit and Christ. In fact, if the Latter is Lord and the third Person is the Spirit of the Lord, then the Spirit must be Lord.

However, the fundamental objection by the Pneumatomachians continues to reappear, with the denial of the possibility of worshiping Him since it is not

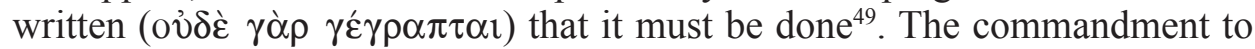
worship the Lord God in 1 Kings 1:23 would therefore be limited to the Son, toward whom the Spirit would lead, as Mt 4:10 seems to state. Here is present in the background an ontological principle that appears fundamental to the Macedonian conception: "Indeed it is necessary that those who approach God

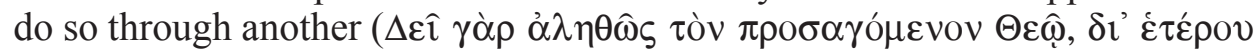

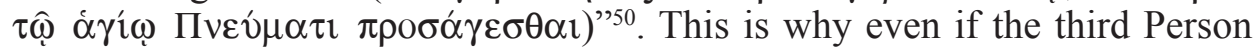
were to be worshiped, we would not understand from this perspective how one would approach the Spirit himself. The example of Nathan who worshiped David serves in the Orthodox response to show how the prophet did not himself violate the commandment in Deut 6:13, which is re-proposed by Jesus in Mt 4:10, to worship God alone, because the Prophet worshiping the Anointed of the Lord worshiped the power of the Spirit ${ }^{51}$.

Therefore, the response continues with the affirmation that the commandment in Deut 6:13 refers to the divine nature and therefore includes the Father, the Son, and the Holy Spirit:

"If, therefore, it is proved that the Spirit who proceeds ( $\dot{\varepsilon} \kappa \chi v \theta \dot{\varepsilon} v)$ from the Father himself through the Son ( $\delta i \dot{\alpha} \tau o \hat{v}$ Yiov) is of the same nature as the Father and of the Son, it is also concluded that He must be worshiped and revered" 52 .

This point is central to the argument, because the Macedonian ontological principle that was first enunciated seems to imply that the relation of worship with a divine Person must always be mediated by an intermediate being, that is, by

\footnotetext{
${ }^{47}$ Cf. ibidem I 2, 27-30.

${ }^{48} \mathrm{Cf}$. ibidem I 3, 1-4.

${ }^{49} \mathrm{Cf}$. ibidem I 4, 2-3.

${ }^{50}$ Ibidem I 4, 12-13, ed. Cavalcanti, p. 56.

${ }^{51} \mathrm{Cf}$. ibidem I 4, 15-25.

${ }^{52}$ Ibidem I 5, 11-14, ed. Cavalcanti, p. 56-58.
} 
an ontological mediator. The procession of the Spirit of the Father through the Son in the divine immanence shows, then, that this metaphysical graduality is excluded. Thus, the impossibility of recognizing Jesus as Lord, affirmed in 1Cor 12:3, is reread in light of the commandment of Jn 4:24 to worship God in Spirit and Truth. The text is interpreted in a Trinitarian way, identifying the Truth with the second Person and the Spirit with the third. Thus, if worshiping God the Father in Spirit and Truth does not imply the exclusion of the worship of Truth itself (that is, the Son), then in the same way worshiping the Father and the Son does not exclude the Spirit. In fact, including the second Person in worship does not diminish the greatness of the first Person, inasmuch as, as is said in Jn 6:44, no one can come to the Son if they are not drawn by the Father who is in Heaven ${ }^{53}$. Ontologically, this means that the condition for being able to approach God is not external to God himself, but is the attraction of the highest principle and not an intermediate being. The possibility of the relation is thus placed not in the divine economy, but in the divine immanence, i.e. in the eternal relations of the three divine Persons. The conclusion of the argument is very clear in this regard:

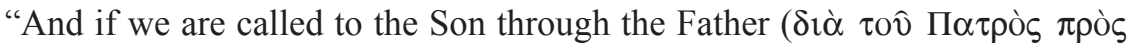
tòv Yiòv), but as a result the Father is no less dignified, then we are also

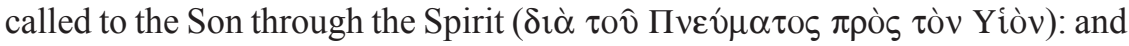
the latter does not lose anything of His dignity, because you know that we are

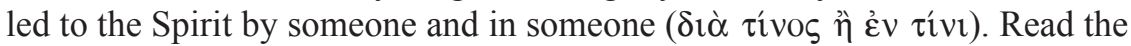
scriptures and learn that as we are led by the Father to the Son, also through the Son we are led to the Father; in fact, as was mentioned ( $\pi \rho \circ \alpha \pi \circ \delta \varepsilon ́ \delta o \tau \alpha \mathrm{l})$, they are reciprocal relations ( $\dot{\alpha} v \tau \imath \sigma \tau \rho \varepsilon \dot{\varphi} \varphi \varepsilon$ ). Therefore, just as through the Father we are led to the Son, so by the Father and the Son we are led to the

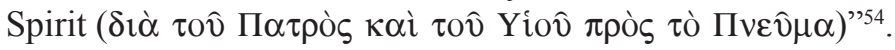

This dogmatic strategy seeks to show the reversibility of the immanent relations, according to a scheme that would be reprised by Gregory of Nyssa, as will be seen later.

Consistently, the argument goes on to discuss Baptism, imparted in the name of the Father, of the Son, and of the Spirit. The issue is framed on the basis of the question of whether Baptism itself or worship is more important. The superiority of the first over the second is proved by the fact that catechumens worship the first two divine Persons, but they do not reach the fullness of Christian life if they do not receive the third through the sacrament ${ }^{55}$. Linked to Baptism is the interpretation of the conumeration ( $\sigma v v \alpha \rho \imath \theta \mu \varepsilon i \tau \alpha \imath)$, which according to the Macedonian reading is reduced to the nominal level: the Spirit

\footnotetext{
${ }^{53}$ Cf. ibidem I 5, 17-27.

${ }^{54}$ Ibidem I 5, 31-38, ed. Cavalcanti, p. 58.

${ }^{55} \mathrm{Cf}$. ibidem I 6, 2-8.
} 
would be conumerated as Spirit alone, and not at the same level as Father, Son, and $\mathrm{God}^{56}$.

It is noteworthy that the dispute over the divinity of the third Person revolves around the identification of the difference between the spirituality and the personal characteristic of the Spirit himself as distinct, in a perfect identity of nature, from the Father and the Son. The orthodox response takes up Ps 81:6 again, rereading it from an angelogical perspective, in order to show the absurdity of the heretical position, which puts the angels alongside God but excludes the Spirit. All of this is designed to highlight the force of the affirmation of the uniqueness of nature:

"We, rather, do not conumerate on the basis of name, since this is not anything great, but on the basis of the nature itself"

The underlying ontological issue is that nothing can be added to or subtracted from the Father, the Son, and the Spirit, because they are perfect in their unique nature ${ }^{58}$.

The penultimate Pneumatomachian objection concerns ó $\mu$ o $1 \mu$ í $\alpha$. If one were to admit that the Spirit can be worshiped, then the honor rendered to Him could not be the same as that rendered to the Father and to the Son, because this is not written $(\dot{\varepsilon} \pi \varepsilon 1 \delta \grave{\eta} \text { o } \delta \dot{\varepsilon} \gamma \gamma \dot{\varepsilon} \gamma \rho \alpha \pi \tau \alpha \mathrm{l})^{59}$. The response touches upon a theological summit, because it rereads Baptism in the name of the three divine Persons as a supreme act of adoration that also involves one's own body, according to what is said in Rom 12:160.

Finally, the last and definitive Pneumatomachian objection regards the creaturality of the Spirit, which is always discussed on the basis of the principle of the what is or is not written, and therefore in reference to the exegesis of Jn 1:3.10. The orthodox response compares the equivocal nature of this position with the duplicity of the Pharisees who are questioned about the baptism of John the Baptist (cf. Mt 21:26). The Macedonian attempt consists in affirming the creaturality of the Spirit, while simultaneously separating Him from all the other creatures. The set of different scriptural passages cited to demonstrate the intimate relation between the Father and the Spirit, from Mt 10:20 to Acts 2:17, converges on the fundamental criticism that the Father could not anoint the Son, who is actually God, with a creature.

From this it follows that the argument of the first and oldest part of the treatise is intended to short-circuit the relationship between the Father and the Son through the Holy Spirit. The affirmation of the divinity of the second Person is utilized to show ad absurdum that only the uniqueness of nature is a sound

\footnotetext{
${ }^{56}$ Cf. ibidem I 6, 16-18.

${ }^{57}$ Ibidem I 6, 27-29, ed. Cavalcanti, p. 60.

${ }^{58} \mathrm{Cf}$. ibidem I 6, 34-36.

${ }^{59} \mathrm{Cf}$. ibidem I 7, 2-3.

${ }^{60} \mathrm{Cf}$. ibidem I 7, 8-18.
} 
basis for the Pneumatomachian reasoning itself, in such a way that the divinity of the Holy Spirit can be affirmed starting from the doxological dimension that characterizes the life and liturgy of the Church. In this process, the relational dimension of the divine immanence is perfectly recognized and highlighted, together with the role of the Son in the procession of the third Person. The issue is genuily metaphysical, inasmuch as the Trinitarian revelation excludes the necessity of an ontologial mediator in the adoration of the divine Person. The scheme of the Macedonian objections could be the following:

1. It is not written that one needs to worship the Spirit;

2. He is Lord but not God: Christological connection;

3. Ontological core: If He were such, there would be no mediator to approach Him;

4. This is why He is conumerated in name only: the Baptismal discourse;

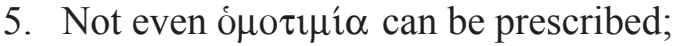

6. Therefore, the Spirit is created but superior to the creatures.

In the response of the Orthodox the essential element is the distinction between the personal dimension and the substantial dimension, founded on the attribution of the names of the three divine Persons to the relational ambit. The basis of this is the denial, based on scripture, of the ontological principle of the necessity of an ontological mediator between the faithful and He who is the object of worship. This is deeply coherent, because the traces of a graduated metaphysical vision exclude the possibility of direct relational contact between God and man, while the relational rereading of the divine immanence introduces a new possibility of expressing the relationship between the creature and the Creator. From this perspective, the mediation of the Son in the procession of the Spirit appears as an intrinsic element to the Trinitarian immanence's personal dynamic, and as an element that is intimately connected to the response to the Pneumatomachian heresy.

b) Second Part. The second part of the first treatise develops arguments with more sophisticated theological tools, in which the influence of the pneumatology of Gregory of Nyssa can be clearly seen. The redactional linking between the first and the second part of the treatise ${ }^{61}$ shows from the beginning the intention of extending the proof of the oneness of nature. The dialogical fictio is proposed as an element of continuity with respect to the refutation of the $\sigma \chi \varepsilon \delta$ óptov in the first part. Thus, the initiative passes to the Orthodox side.

The outline of the proof ad absurdum is subsequently repeated: a. Only God is immortal; b. But the angels are immortal as well; $c$. And both sides converge on the fact that the angels are immortal due to participation $(\mu \varepsilon \tau \circ \chi \hat{\eta}) ; \mathrm{d}$. So, the Orthodox leads the Macedonian to recognize that the Son is immortal

\footnotetext{
${ }^{61}$ Cf. ibidem I 9, 1-5.
} 
like the Father and not because of participation; e. In the end the issue about the Holy Spirit is repeated - that His immortality is recognized by the Macedonian as being like that of the Father and of the Son and not because of participation like the angels; $f$. In this way one gets to the nonsense that God is not the only one to be perfectly immortal, at least if it is not accepted that the Father, the Son, and the Spirit are a single nature ${ }^{62}$.

Different theological elements recall in particular the Ad Ablabium of Gregory of Nyssa, such as the discussion about tritheism, which immediately follows the demonstration of immortality. This treatise by Gregory most likely dates back to the 490's A.D. and likely follows the first part of the PseudoAthanasian treatise but comes before the second. The Father, the Son, and the Spirit are identified with the one immortal nature while being three distinct hypostases. The example of Paul, Peter, and Timothy is analogous to this ${ }^{63}$. The Pneumatomachian response seeks to undermine the parallelism by highlighting how the men cited have originated from other men, while the Orthodox argument concludes by affirming that there was nothing prior to three divine Persons, but that their origin is immanent and is linked to the processions $\left(\dot{\alpha}^{\prime} \lambda \lambda^{\prime} \dot{\varepsilon} \kappa\right.$

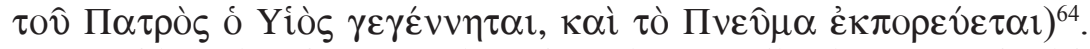

At this point the reasoning about immortality is repeated with regard to holiness, always proceeding by means of a comparison with the angels, to conclude with the Holy Spirit's activity as a sanctifier ${ }^{65}$. The discussion shifts to

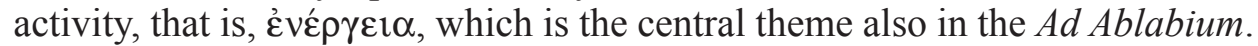
It is in this direction that the following section seems to go, and it applies the demonstration that was already seen with immortality to the fact of the Holy Spirit's being a guide. Here is repeated the Orthodox ontological principle that where there is identity of action, there must also be identity of nature - which

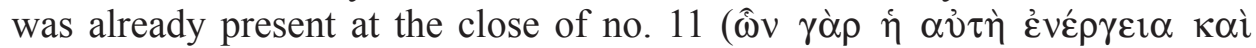

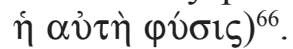

The equality of the Spirit with regard to the Father and to the Son is put in terms of the identity between gold and gold ${ }^{67}$. Immediately following, the classic Pneumatomachian objections reappear, that is, the statement that if the Spirit were God, then He and the Son would be brothers ${ }^{68}$. The Orthodox response rests on the difference between these two processions ('A $A \lambda \lambda^{\prime}$ 'o $\mu \dot{\varepsilon} \nu$ Yiòs

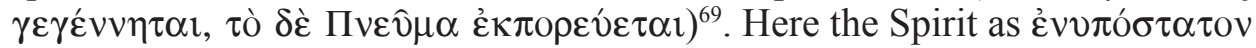
comes into play. The reasoning springs from the fact that a living being that is

${ }^{62}$ Cf. ibidem I 9, 6-34.

${ }^{63}$ Cf. ibidem I 10, 4-7.

${ }^{64}$ Cf. ibidem I 10, 13-17, ed. Cavalcanti, p. 68.

${ }^{65}$ Cf. ibidem I 11, 1-77.

${ }^{66} \mathrm{Cf}$. ibidem I 12, 14-15, ed. Cavalcanti, p. 74. The expression is repeated in I 12, 35-36, ed. Cavalcanti, p. 76; I 13, 24, ed. Cavalcanti, p. 80; and I 16, 8-9, ed. Cavalcanti, p. 86.

${ }^{67}$ Cf. ibidem I 12, 57-62.

${ }^{68} \mathrm{Cf}$. ibidem I 14, 21.

${ }^{69}$ Cf. ibidem I 14, 25, ed. Cavalcanti, p. 82. 
also characterized by rational activity and that is mortal is evidently a human. In the same way, if the Spirit is hypostatic, sanctifying, and uncreated then $\mathrm{He}$

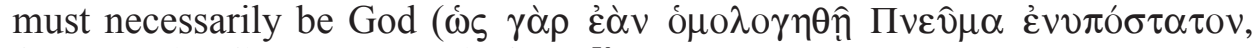

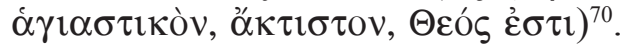

At this point there is interjected the Pneumatomachian objection that aims to distinguish the fact of being God from that of being divine ${ }^{71}$. The response passes

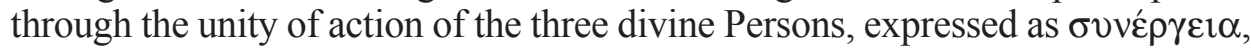
up to the question about the regality of the Spirit posed by the Orthodox to the Macedonian: with the latter recognizing the regality only of the first two divine

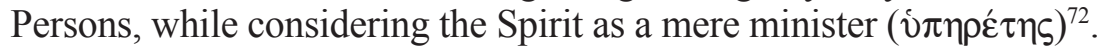

In the following section the tritheistic objection returns, where the essential point of distance is the orthodox identification between the $\sigma v \mu \varphi \omega v i \alpha$ and the identity of nature of the three divine Persons. The Macedonian side, on the other hand, welcomes the first and denies the second ${ }^{73}$. Nevertheless, the identity of the attributes that were already proven should lead to the conclusion that the third Person should not be subordinate to the first two ${ }^{74}$. The discussion about the different ways of understanding being placed beneath another and being greater than another in Scripture leads to the Macedonian affirmation that the Spirit is not created but is made ${ }^{75}$. The scriptural reference is evidently the Johannine prologue and the affirmation that all things were made through the Son (cf. Jn 1:3.10). Here, we see the literalist principle that characterizes the Pneumatomachian heresy in action. From the Orthodox side it is argued that based on the distinction between being made and being created (which the opposition supports) they would need to deduce from the verse that not everything has been created. The Macedonian reveals that the scope of his dogmatic position is to recognize a difference of dignity between different creatures. For the Spirit this difference concerning the Father and the

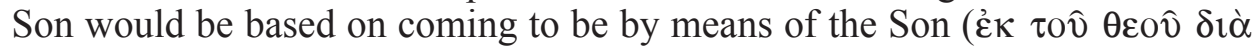

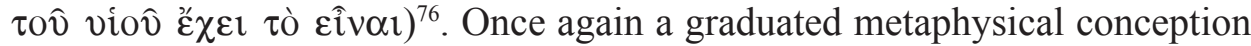
makes its appearance. This also explains the importance of the role of the Son in the procession of the Spirit emphasized by the first part of the treatise. All of the orthodox reasoning aims to show, on one hand the equivalence between being made and being a creature, and, on the other hand, the affirmation that only the three divine Persons are not creatures and are not made, but that they are distinguished from each other in the immanence, as the Spirit is $\alpha \gamma \varepsilon \dot{\varepsilon} v \eta \tau$ v

\footnotetext{
${ }^{70}$ Cf. ibidem I 15, 6-10, ed. Cavalcanti, p. 84.

${ }^{71}$ Cf. ibidem I 15, 22.

${ }^{72}$ Cf. ibidem I 17, 15-20.

${ }^{73}$ Cf. ibidem I 18, 27-29.

${ }^{74}$ Cf. ibidem I 18, 37-40.

${ }^{75} \mathrm{Cf}$. ibidem I 20, 2.

${ }^{76}$ Cf. ibidem I 20, 19, ed. Cavalcanti, p. 104.
} 


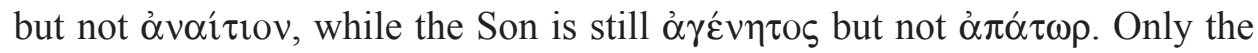
first Person, however, can be characterized by all three adjectives ${ }^{77}$.

The treatise concludes with a discussion of the exegesis of the Baptism of Jesus in Jn 1:33 where the Spirit is placed by the Father over the Son. The Macedonian reading is that here the reference is to God as Spirit, while the Orthodox response proceeds by identifying the Spirit who appears in this mo-

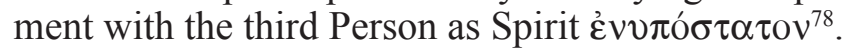

The second treatise seems important for determining the relationship between the Macedonians and the Homoiousians, in addition to the role of apollinarism, but its analysis is beyond the scope of the current work ${ }^{79}$.

In a very brief summary, the strategy of response contained in the pneumatology of these treatises apparently aims at discerning the role of the Son in the procession of the Spirit, which the Macedonian reading places at the economical level and the Orthodox at the immanent one.

3. Gregory of Nyssa's Adversus Macedonianos. The treatise Adversus Macedonianos presents a completely different situation with respect to the other works analyzed, both from a philological standpoint and an historical standpoint ${ }^{80}$. It is transmitted only in a single thirteenth century codex ${ }^{81}$. The datings of the work all converge around the years 380-381, therefore, in the context of the discussions for responding to the Pneumatomachian heresy in the ambit of the Council of Constantinople ${ }^{82}$.

After a brief rhetorical introduction (89, 1-15), the treatise can be divided into three main parts, based on different passages of theological argumentation, which are marked by partial conclusions concerning the necessity of worshiping the Holy Spirit.

The first part, dedicated to the formulation of the question, goes from 89, 16 to 92,9 . Here is presented the accusation of sacrilege hurled by the Macedonians against the Orthodox, based on the argument that the Spirit would not create because Scripture does not affirm it. Gregory's response affirms the identity between the divine being and the full possession of every good. He writes: "divine has perfection according to every meaning of Goodness

${ }^{77}$ Cf. ibidem I 20, 25-36, ed. Cavalcanti, p. 104.

${ }^{78} \mathrm{Cf}$. ibidem I 20, 59.

${ }^{79}$ Cf. ibidem II 157-166.

${ }^{80}$ On this work, see: V.H. Drecoll, Adversus Macedonianos de Spiritu Sancto, in: The Brill Dictionary of Gregory of Nyssa, ed. L.F. Mateo-Seco - G. Maspero, Leuven 2009, 466-468; E.D. Mout-

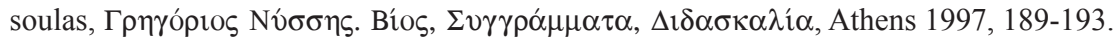

${ }^{81}$ Cf. F. Mueller, Praefatio, in: Gregorius Nyssenus, Opera dogmatica minora, GNO 3/1, Leiden 1958, XLVIII.

${ }^{82}$ Cf. J. Daniélou, La chronologie des auvres de Grégoire de Nysse, StPatr 7 (1966) 163; G. May, Die Chronologie des Lebens und der Werke des Gregor von Nyssa, in: Ecriture et culture philosophique dans la pensée de Grégoire de Nysse, ed. M. Harl, Leiden 1971, 59. 


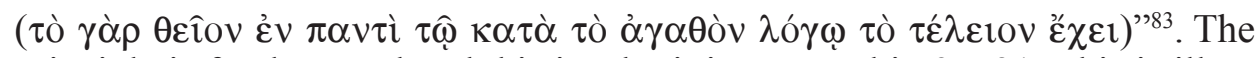
principle is fundamental and this is why it is repeated in 95, 21. This is illustrated though the material examples of fire, water, and air; all of which are elements that are symbolically connected to the third divine Person, to conclude with the identity of nature. This immediately follows the principle enunciated, as these examples illustrate how one cannot preach the increase or decrease of what is perfect:

"When we confess, according to the teaching of Scripture and from the common concepts, that the Spirit is of divine nature, we think of no difference, such that the divine and transcendental nature, distributing itself to itself, would change itself into itself by tension or relaxation in greater and lesser degrees" $"$.

What is essential here is to find at the same time a double reference to Scripture and to common notions, that is, to the ordinary metaphysical conception. In fact, the Pneumatomachian position refers exclusively to the reading of the biblical text, prescinding from the value of its interpretation and, therefore, from the search for a sense that is open to the rational comprehension of each person. However, if the Holy Spirit creates, it immediately follows from this that the cosmic dimension, and therefore the object of philosophical study, has a positive value and is a valid path in search of the truth.

The second section, which revolves around the theological consideration of the divine attributes, goes from 92, 10 to 97, 10. The Spirit is perfectly identified with all of the attributes themselves, beyond any participation. This shows, also through the parallel with three torches and with the human being, that order does not necessarily imply participation ( $\left.\varepsilon^{\prime \kappa} \mu \varepsilon \tau 0 v \sigma i \alpha \varsigma\right)$. For this reason, if the Spirit is perfect then He must necessarily be God. This is applied to the attribute glorious, which is understood in a perfect way as infinite and eternal: "for a being that is not perfectly honorable is conceived to partake

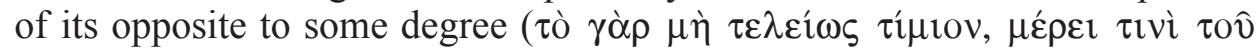

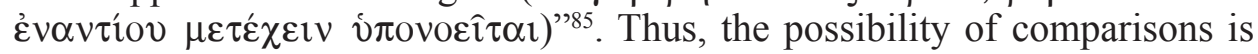
in fact excluded. Therefore, the same honor that is attributed to the first two Persons is due to the third, and this implies that man cannot render this honor to Him in a way that is worthy:

"How will you honor the divine? How will you exalt the most exalted? How will you glorify what is above all glory? How will you praise the incomprehensible?"»66.

${ }^{83}$ Gregorius Nyssenus, Adversus Macedonianos de Spiritu Sancto, ed. F. Mueller, GNO 3/1, 91, 7-8.

${ }^{84}$ Ibidem, GNO 3/1, 90, 27 - 91, 2.

${ }^{85}$ Ibidem, GNO 3/1, 94, 29-30.

${ }^{86}$ Ibidem, GNO 3/1, 96, 23-25. 
The line of reasoning follows from the preceding section, because if what is ontologically perfect does not know levels ${ }^{87}$ then the Holy Spirit, inasmuch as $\mathrm{He}$ is divine and consequently perfect, not only possesses every divine attribute, but is identified with it $(91,10-94,2)$. However, if this is applied to the glorious being, it can be deduced that the third Person must be such in an infinite and eternal way $(94,2-95,26)$. From here we reach the conclusion of the necessity of rendering unto Him an infinite worship that per se is beyond human capacities $(95,27-97,20)$. To think of being able to give homage to the third Person in an adequate way would be like trying to add light to the rays of the sun with a small candle ${ }^{88}$.

The third part, which consists of 97, 21 and 113, 23 and is dedicated to the connection between the economy and the immanence, returns to the Pneumatomachian objection that Scripture does not affirm anywhere that the Spirit has created. This objection is confronted with a question: what was the Holy Spirit then doing at the moment of creation? This is a rhetorical question which introduces the reader to the core of Gregory's response, by introducing the unity of action:

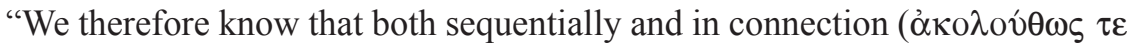

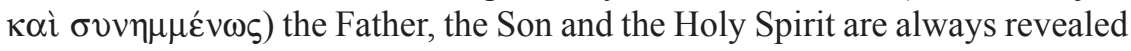
with each other in a perfect triad, and before all creation, before all the ages and before any conceptual apprehension the Father is always Father, the Son is in the Father and the Holy Spirit is with the Son" $"$.

The direction of Gregory's argumentation is from name to action and from action to being. The starting point is once again the logical passage formulated in the preceding part, because now the connection between perfection and glory is extended in the sense of eternity. From action one can pass to being, showing how the one divine action springs from within the Trinity itself:

"every nature substantiated ( $(\pi 0 \sigma \tau \hat{\alpha} \sigma \alpha \nu$ ) through creation could reasonably be said to be a movement of will, excitement of purpose and transmission of power, that originates from the Father, proceeds through the Son and is perfected in the Holy Spirit" ${ }^{\prime 9}$.

The resulting necessity to worship the Creator leads to the recognition that without Him we cannot be called Christians. This demonstration joins the economy and the immanence, rising up from the anointing of Christ to the identification of the personal proprium of the Spirit ${ }^{91}$ as the royal power that

\footnotetext{
${ }^{87} \mathrm{Cf}$. ibidem, GNO 3/1, 95, 22-26.

${ }^{88}$ Cf. ibidem, GNO 3/1, 97, 1-7.

${ }^{89}$ Ibidem, GNO 3/1, 98, 28 - 99, 1.

${ }^{90}$ Ibidem GNO 3/1, 100, 7-11.

${ }^{91}$ Cf. ibidem GNO 3/1, 90, 1-4.
} 
the Father and the Son eternally exchange, and Who without any ontological intermediary constitutes the kingship of each of the first two divine Persons:

"So if the Son is king by nature, and the chrism is a symbol of his kingship, then what does the logic of the reasoning mean to you? That the chrism is not something foreign to the natural king, and we do not classify the Spirit with the Holy Trinity as a stranger and foreigner. Indeed the Son is king. But the Holy Spirit is the living, substantial and subsistent kingship ( $\zeta \hat{\omega} \sigma \alpha \kappa \alpha i$

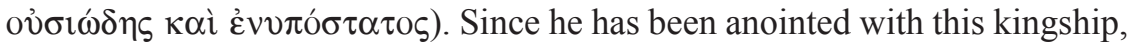
the only-begotten Christ is also king of all existing things. So if the Father is king and the Only-begotten is king and the Holy Spirit is kingship, the reason for kingship in the case of the Trinity is absolutely the same" ${ }^{\prime \prime 2}$.

Here, we are at one of the summits of Greek pneumatology, inasmuch as the denial of the divinity of the Holy Spirit on the part of those who, rather, accept the Son's divinity, are answered by Gregory through the location of the third Person among the first and the second. The solution is facilitated by the knowledge of the Syriac version of the Lucan text of the Our Father, where the "Your Kingdom come" becomes "May your Spirit come upon us and purify us" "93. As we have seen in the previous section, the argument of the kingship of the third Person reappears in the discussions with the Macedonians.

The solution is very effective because it respects the monarchy of the Father, who is the unique source of the Regality, and the identity of nature with the Son, who in His turn is King, insofar as the two eternally and perfectly exchange the royal power that is the Spirit Himself. The strategy that, after Athanasius, had always been followed to demonstrate the divinity of the Son through the correlativity of the names of the first two divine Persons is extended here to the third Person, reinterpreting His name in a sense that is correlative to the Father and the Son.

Underpinning this theological rereading of the scriptural texts concerning regality is the formulation of an ontological principle that undermines the metaphysical hierarchy that is typical of Greek philosophy:

"Reason recognizes nothing intermediary ( $\mu \varepsilon ́ \sigma o v)$, so that some special bor$\operatorname{der}(\hat{\varepsilon} v \mu \varepsilon \theta$ opí $\omega)$ nature be thought to exist between ( $\mu \varepsilon \tau \alpha \xi \hat{v})$ the created and the uncreated, so that it partakes of both and is neither perfectly"94.

The perfection of the divine nature implies that there cannot be an intermediate level between the Creator and creation. For this reason, from here the text

${ }_{92}$ Ibidem GNO 3/1, 102, 22-31.

${ }^{93}$ Cf. idem, De oratione dominica, ed. J.F. Callahan, GNO 7/2, Leiden - New York - Köln 1992, 39, 15-19. See, in this regard: M. Alexandre, La variante de Lc 11, 2 dans la Troisème Homélie sur l'Oraison Dominicale de Grégoire de Nysse et la controverse avec les pneumatomaques, in: Grégoire de Nysse: La Bible dans la construction de son discours. Actes du colloque de Paris, 9-10 février 2007, ed. M. Cassin et alii, Paris 2008, 163-189.

${ }^{94}$ Gregorius Nyssenus, Adversus Macedonianos de Spiritu Sancto, GNO 3/1, 104, 8-12. 
passes immediately to the reformulation of the argument concerning Regality in terms of ontological glory, with a presentation of the divine immanence through the dynamic of mutual gift that characterizes the three. The journey can be summarized in three passages. First, the Spirit himself is identified with the glory of the Son:

"One who reverently accepts the Spirit sees the glory of the Only-begotten in the Spirit, and when he sees the Son he sees the image of the unlimited, and the archetype is impressed in his mind through the image" 95 .

To this distinction between glory, referring to the third Person, and image, applying to the second, corresponds the distinction between the two eternal processions $^{96}$. Therefore, the relationships between the third Person and both of the first two are reformulated in terms of glory itself, highlighting the reciprocity:

"So the Spirit glorifies the Father and the Son. But he is not a liar who says, I glorify those who glorify me (1Sam 2:30). I glorified you (Jn 17:4) says the Lord to the Father. And again, Glorify me with the glory that I had with you from the beginning before the world existed (Jn 17:5). The divine voice responds, I glorified you and will glorify you again (Jn 12:28)"'97.

The text develops a strict parallelism between the reciprocity in the exchange of glory between the Spirit, on the one hand, and the Father and the Son, on the other, and the reciprocity of the mutual exchange of glory between the latter two. Therefore, the first two divine Persons glorify the third, in that same eternal exchange of glory that characterizes their relationship. The use of prepositions emphasizes the dynamic of this perfect Latreutical act, which here is read in a purely ontological lens in the immanence of the first principle:

"Do you see the cyclical revolution of glory through the same actions? The Son is glorified by ( $\dot{\pi} \pi$ ) the Spirit. The Father is glorified by (i $\left.\pi_{0}\right)$ the Son. Again, the Son has glory from ( $\pi \alpha \rho \alpha$ ) the Father, and the only-begotten becomes the glory of the Spirit. In what will the Father be glorified if not in the true glory of the Only-begotten One? In what again will the Son be glorified if not in the grandeur of the Spirit? So, entering this circular movement, reason (ó $\lambda$ ó ${ }^{\circ}$ ) glorifies the Son through $\left(\delta \iota^{\prime}\right.$ ) the Spirit, and the Father through ( $\delta$ ió) the Son" $"$.

This has immediate repercussions on worship, which is presented in its metaphysical dimension. Thus, negatively, blasphemy against the Holy Spirit proves the divinity of the third Person ${ }^{99}$, while positively, His worship must

\footnotetext{
${ }^{95}$ Ibidem, GNO 3/1, 107, 10-13.

${ }^{96} \mathrm{Cf}$. Athanasius, Epistula ad Serapionem III 1, 2.

${ }^{97}$ Gregorius Nyssenus, Adversus Macedonianos de Spiritu Sancto, GNO 3/1, 109, 2-7.

${ }^{98}$ Ibidem, GNO 3/1, 109, 7-15.

${ }^{99}$ Cf. ibidem, GNO 3/1, 106, 30 - 107, 2.
} 
essentially be configured as supplication, due to the infinite ontological distance that separates humans from Him.

The conclusion, which can be assigned to the text in 114, 5-21, introduces what could be defined as a form of liturgical apophatism, due to the affirmation that nobody can offer adequate worship to the third Person, inasmuch as God always remains beyond the possibilities of man, infinitely more than the distance between our bodies and the stars ${ }^{100}$. The third Person Himself has no need of His own glory since His divine nature consists of the eternal exchange of ontological glory in the Trinitarian immanence. Thus, man radically does not possess anything that can be worthy of God, which is why the only way to pay homage to the Trinity is by offering everything, that is, one's own freedom, like in the example of the widow in Mk 12:42 ${ }^{101}$.

At the end of the proposed journey it can be concluded that all three of the anti-Macedonian treatises analyzed respond to the same accusation by the Pneumatomachians: the Holy Spirit is not to be worshiped because He is not God, in that He does not create, as is deduced from the fact that it is not written in any passage in Scripture. The strategies for refuting these positions must avoid allowing that the second and the third Person of the Trinity could be read as if they were two sons. In the same way, one should emphasize the distinction between the procession of the Spirit ad intra and the production ad extra of the creatures, for which reason the climb proceeding to the origin must stop at the Father, without extending the generation into another generation, as is the case for man. At the base of the response, of course, one can see the inspiration of Athanasius who rereads Jn 4:24 in an immanent and personal sense, identifying the $\pi v \varepsilon \hat{v} \mu \alpha$ cited there with the Holy Spirit and the $\dot{\alpha} \lambda \dot{\eta} \theta \varepsilon i \alpha$ with the Son ${ }^{102}$.

The more scriptural strategy used by Epiphanius of Salamis reconnects the affirmation of the divinity of the third Person to that of the first two through derivative formulae. This is why he emphasizes how the Spirit proceeds both from the Father and from the Son, inasmuch as He is God as Spirit from Spirit. Like in Origen, the fundamental exegetical reference is the affirmation that God is $\pi v \varepsilon \hat{v} \mu \alpha$ always in Jn 4:24, which now, however, is reread in personal terms, concluding that the $\pi v \varepsilon \hat{v} \mu \alpha$ itself is God.

The theology that underpins Dialogus I contra Macedonianum runs, rather, in a more refined way from an ontological perspective, distinguishing the level of nature from that of the Persons, on the basis of relation. This implies that for the worship of a divine Person an intermediate metaphysical level is not necessary: a level which, like substance, separates the worshiper from

\footnotetext{
${ }^{100}$ Cf. ibidem, GNO 3/1, 115, 3-4.

${ }^{101}$ Cf. ibidem, GNO 3/1, 114, 5-21.

${ }^{102} \mathrm{Cf}$. Athanasius, Contra gentes 46, 17-21.
} 
the deity worshiped. This explains the importance of Christological reflection and a deepening of the relationship between the economy and the immanence through analysis of divine action. At different points, especially in the second part, there is noticeable consonance with the pneumatology of Gregory of Nyssa, especially as it appears in his most mature formulation in Ad Ablabium, at the end of his life. In fact, here emerges the center of the question of the role of the Son in the procession of the Holy Spirit: if based on Jn 1:3.10 everything was created by means of the Word, then it is necessary to determine whether the third Person is from Him and therefore is a creature, as the Pneumatomachians tend to affirm, or if the origin through the Son of the Spirit is immanent. This is why the two previous works have been compared to Gregory's treatise Adversos Macedonianos, written nearly fifteen years before the Ad Ablabium. In Adversos Macedonianos, the two prior approaches find an integration, inasmuch as the Spirit is presented as regal Power and hypostatic Glory that the Father and the Son eternally exchange. The reciprocity of the relationship between the Father and the Son, on the one hand, and the Spirit, on the other, which seems to be the center of Epiphanius' approach, becomes united to a more linear conception of the relationship between the divine Persons, in such a way that the giving of glory from one Person to another is always present in the reciprocity. Thus, if the Father renders glory to the Son and the Son to the Father, the Spirit is also glorified, inasmuch as He receives glory from the Father and Son together. The reciprocity of the relationship between the first two divine Persons - an ontological translation of their numerical identity of nature from the correlativity of their personal identity as the eternal Father and Son - is extended to the relationship between the second and the third divine Person, through a rereading of the personal characteristic of the Spirit Himself as correlative to the Father and to the Son. Thus, what unites the three strategies is the search for the affirmation of the divinity of the third Person by tracing it back to the relationship between the first two. Gregory succeeds in formulating in a complete way the insertion of the Spirit among the Father and the Son, without violating the monarchy and by presenting Him in relative terms to the Divinity that they perfectly, eternally, and reciprocally communicate to one another. Such a result would then be developed in the affirmation of the immanent role of the Son in the procession of the Spirit in Ad Ablabium.

The proximity of the theologies that have been presented is emphasized by

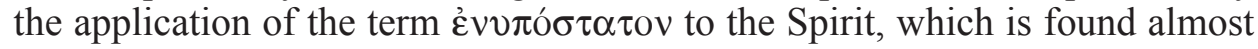
exclusively in Gregory, Ephiphanius, and the Pseudo-Athanasius of the Dia$\log i$ and De Trinitate ${ }^{103}$. It is precisely this point of arrival that reveals how the Pneumatomachian criticisms have forced the deepening of the understanding

${ }^{103}$ The phenomenon is also present in the Pseudo-Didymus of De Trinitate (PG 39, 648A). It later it appears in the Theodoret (cf. Theodoretus, Graecarum affectionum curatio II 110, 4) and in the Damascene (cf. Joannes Damascenus, Sacra parallela, PG 95, 1076B and Contra Manichaeos $28,41)$ here in immediate reference to the controversy concerning the Filioque. 
of the distinction between the two processions to clarify the difference between the spirit as substantial attribute of God and the Spirit as third divine Person, that is, as hypostasis.

\section{(Summary)}

Different sources describe the theology of the Pneumatomachians or Macedonians in the $4^{\text {th }}$ century. They shared with the Arians the negation of the divinity of the Holy Spirit but were in disagreement with them about the Son. Different Greek Fathers wrote different answers and the study of their strategies seems of interest to better understand the heresy itself and its varieties. Epiphanius of Salamis, both in Ancoratus 65, 1 - 73, 9 and in Panarion 54 (74), presents a description of the Pneumatomachian heresy with a series of arguments to counter it. Equally important seem the Dialogi duo contra Macedonianos (PG 28, 1291-1338), transmitted in Athanasius' Corpus, later attributed to Didymus, and still of discussed authorship. The comparison of these different works on the background of Cappadocian pneumatology, in particular Basil's De Spiritu Sancto and Gregory of Nyssa's Adversus Macedonianos, may offer interesting insights from both the historical and theological perspective.

\section{RÓŻNE STRATEGIE GRECKICH OJCÓW WOBEC DUCHOBURCÓW}

\section{(Streszczenie)}

Różnorodne źródła prezentują teologię duchoburców (macedonian, pneumatomachów) w IV wieku, którzy wraz z arianami negowali bóstwo Ducha Świętego, ale w przeciwieństwie do nich nie kwestionowali tego odnośnie do Syna. Ojcowie greccy toczyli z nimi różne dysputy, a badanie ich strategii wydaje się być interesujące, by lepiej zrozumieć samą herezję i jej odmiany. Epifaniusz z Salaminy, zarówno w Ancoratus 65, 1 - 73, 9, jak i w Panarionie 54 (74), opisuje herezję duchoburców, a także przedstawia szereg argumentów przeciw nim. Równie ważny wydaje się być traktat Dialogi duo contra Macedonianos (PG 28, 12911338), przekazany w korpusie pism Atanazego, później przypisywany Dydymowi Aleksandryjskiemu, o którego autorstwo nadal jeszcze toczą się dyskusje. Porównanie tych różnych dzieł na tle pneumatologii Ojców Kapadockich, zwłaszcza De Spiritu Sancto Bazylego z Cezarei i Adversus Macedonianos Grzegorza z Nyssy, może przynieść ciekawe wnioski, zarówno z perspektywy historycznej, jak i teologicznej.

Key words: Greek Fathers of the Church, Pneumatomachians, Pneumatology.

Słowa kluczowe: greccy Ojcowie Kościoła, duchoburcy, pneumatologia. 


\section{BIBLIOGRAPHY}

Sources

Athanasius, Contra gentes, ed. R.W. Thomson, Oxford 1971.

Athanasius, Epistulae ad Serapionem, PG 26, 529-648.

EpIPHAnius, Ancoratus, ed. K. Holl, GCS 25, Leipzig 1915, 1-149.

EpIPHAnius, Panarion, ed. K. Holl, GCS 25, Leipzig 1915; GCS 31, Leipzig 1922; GCS 37, Leipzig 1933.

Gregorius Nyssenus, Adversus Macedonianos de Spiritu Sancto, ed. F. Mueller, in: Gregorius Nyssenus, Opera dogmatica minora, GNO 3/1, Leiden 1958, 87-115.

Gregorius Nyssenus, De oratione dominica, ed. J.F. Callahan, GNO 7/2, Leiden - New York - Köln 1992.

Hieronymus, Chronicon, ed. R. Helm, GCS 47, Eusebius Werke 7, Berlin 1956.

Joannes Damascenus, Contra Manichaeos, PG 94, 1505-1584.

Joannes Damascenus, Sacra parallela, PG 95 - 96, 9-466.

Pseudo-Athanasius, Dialogi contra Macedonianos, ed. E. Cavalcanti, Corona Patrum 10, Torino 1983.

Pseudo-Epiphanius, Anacephalaeosis, ed. K. Holl, GCS 25, Leipzig 1915, 162-168 and 234-237; GCS 31, Leipzig 1922, 1-4, and 211-214; GCS 37, Leipzig 1933, 1-2, 230232 and 415.

Pseudo-Joannes Chrysostomus, De eleemosyna, PG 60, 707-712.

Theodoretus, Graecarum affectionum curatio, ed. P. Canivet, SCh 57, Paris 1958.

\section{Literature}

Alexandre M., La variante de Lc 11, 2 dans la Troisème Homélie sur l'Oraison Dominicale de Grégoire de Nysse et la controverse avec les pneumatomaques, in: Grégoire de Nysse: La Bible dans la construction de son discours. Actes du colloque de Paris, 9-10 février 2007, ed. M. Cassin et alii, Paris 2008, 163-189.

Bizer Ch., Studien zu pseudathanasianischen Dialogen der Orthodoxos und Aëtios, Bonn 1970.

DaniÉlou J., La chronologie des œuvres de Grégoire de Nysse, StPatr 7 (1966) 159-169.

Drecoll V.H., Adversus Macedonianos de Spiritu Sancto, in: The Brill Dictionary of Gregory of Nyssa, ed. L.F. Mateo-Seco - G. Maspero, Leuven 2009, 466-468.

Drecoll V.H., Die Entwicklung der Trinitätslehre des Basilius von Cäsarea. Sein Weg vom Homöusianer zum Neonizäner, Göttingen 1996.

Drecoll V.H., How Binitarian/Trinitarian was Eusebius?, in: Eusebius of Caesarea. Tradition and Innovations, ed. A. Johnson - J. Schott, Cambridge 2013, 289-305.

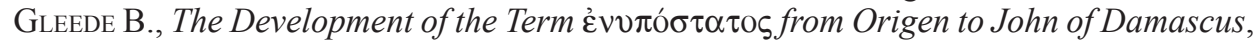
Leuven 2012.

GüNTHÖR A., Die 7 pseudoathanasianischen Dialogen ein Werk Didymus'des Blinden von Alexandrien, Dissertation, Pontifical Atheneum of St. Anselm, Roma 1940.

Gwynn D.M., The Eusebians. The Polemic of Athanasius of Alexandria and the Construction of the "Arian Controversy", Oxford 2007.

Hauschild W.-D., Die Pneumatomachen. Eine Untersuchung zur Dogmengeschichte des vierten Jahrhunderts, Hamburg 1967 (PhD thesis).

Haykin M.A.G., The Spirit of God: The Exegesis of 1 and 2 Corinthians in the Pneumatomachian Controversy of the Fourth Century, Leiden 1994.

Kretschmar G., Studien zur frühchristlichen Trinitätstheologie, Tübingen 1956. 
Larson M.J., A Re-examination of De Spiritu Sancto: Saint Basil's Bold Defence of the Spirit's Deity, „Scottish Bulletin of Evangelical Theology” 19 (2001) 65-84.

Maspero G., Dallo Spirito vivificatore allo Spirito Creatore: l'esegesi cappadoce di Sal 32(33),6, in: Creazione e salvezza nella Bibbia: atti dell'XI Convegno internazionale della Facoltà di teologia, Roma, 8-9 marzo 2007, ed. M.V. Fabbri - M. Tábet, Roma 2009, 407-426.

Maspero G., Life from Life: The Procession of the Son and the Divine Attributes in Ch. VIII of Gregory of Nyssa' a Contra Eunomium III, in: Gregory of Nyssa's Contra Eunomium III. Proceedings of the Twelfth International Gregory of Nyssa Colloquium (Leuven, 14-17 September 2010), ed. J. Leemans - M. Cassin, Leuven 2014, 401-428.

May G., Die Chronologie des Lebens und der Werke des Gregor von Nyssa, in: Ecriture et culture philosophique dans la pensée de Grégoire de Nysse, ed. M. Harl, Leiden 1971, 51-66.

MeInhold P., Pneumatomachoi, RACh XXI 1066-1087.

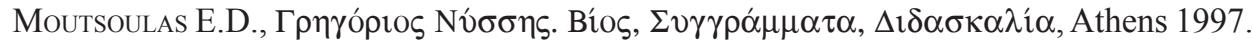

Mueller F., Praefatio, in: Gregorius Nyssenus, Opera dogmatica minora, GNO 3/1, Leiden 1958, IX-LXI.

Segovia A., Contribucion al estudio de la tradicion manuscrita dei pseudoatanasiano. "Dialogo I contra un Macedoniano o pneumatomaco", "Archivio Teológico Granadino" 1 (1938) 87-107.

Strutwolf H., Die Trinitätstheologie und Christologie des Euseb von Caesarea. Eine dogmengeschichtliche Untersuchung seiner Platonismusrezeption und Wirkungsgeschichte, Göttingen 1999. 
